\title{
Manajemen Strategi: Aplikasi Pada Perusahaan Cargo Udara di Bandara Untuk Memenangkan Persaingan Bisnis
}

\section{Strategic Management: Applications In Air Cargo Companies at the Airport To Win Business Competition}

\author{
Vica Nurhayani Harahap ${ }^{1 *}$, Primadi Candra Susanto ${ }^{2}$ \\ 1,2, Institut Transportasi dan Logistik TRISAKTI, Jakarta, Indonesia \\ *Penulis koresponden : harahapvica@gmail.com
}

\author{
ARTICLE INFO \\ PBJ use only: \\ Received date 8 Agustus 2020 \\ Revised date 5 September 2020 \\ Accepted date 12 November 2020
}

\begin{abstract}
The purpose of this study is to see the success of the concept of strategic management to support the operational activities of cargo companies at airports to be able to win business competition from similar competitors. Strategic management in general can be perceived as the art and science of preparing, implementing, and evaluating decisions, strategic management. focuses on the process of setting organizational goals, developing policies and planning to achieve goals, and allocating resources to implement policies and plan for achieving organizational goals. Strategic management combines the activities of various functional parts of a business to achieve organizational goals. There are three stages in strategic management, namely strategy formulation, strategy implementation, and strategy evaluation. The Indonesian transportation sector is experiencing significant growth, especially the air cargo company business, in this case not all types of goods can be sent via air cargo, shipping via air is indeed faster.
\end{abstract}

Keywords : Strategic Management; Air Cargo; Airport; Winning Business 


\begin{abstract}
ABSTRAK
Tujuan penelitian ini adalah untuk melihat keberhasilan konsep manajemen strategi untuk mendukung kegiatan operasional perusahaan cargo di bandar udara untuk dapat memenangkan persaingan bisnis dari pesaing sejenis, Manajemen strategis secara umum dapat dipersepsikan sebagai seni dan ilmu penyusunan, penerapan, dan pengevaluasian keputusan keputusan, manajemen strategis berfokus pada proses penetapan tujuan organisasi, pengembangan kebijakan dan perencanaan untuk mencapai sasaran, serta mengalokasikan sumber daya untuk menerapkan kebijakan dan merencanakan pencapaian tujuan organisasi. Manajemen strategis mengkombinasikan aktivitas-aktivitas dari berbagai bagian fungsional suatu bisnis untuk mencapai tujuan organisasi. Ada tiga tahapan dalam manajemen strategis, yaitu perumusan strategi, pelaksanaan strategi, dan evaluasi strategi. Sektor transportasi Indonesia mengalami pertumbuhan yang signifikan terutama bisnis perusahaan cargo udara, dalam hal ini tidak semua jenis barang dapat dikirim melalui cargo udara, pengiriman lewat jalur udara memang lebih cepat sampai.
\end{abstract}

Kata kunci : Manajemen Strategi; Cargo Udara; Bandar Udara; Memenangkan Bisnis

\title{
A. PENDAHULUAN
}

Perkembangan pengiriman barang via udara ataupun laut yang lebih dikenal dengan sebutan kargo, pada saat ini mengindikasikan perkembangan yang mengembirakan. Hal ini terlihat dari makin banyaknya perusahaan kargo yang worldwide. Federal express, TNT, UPS, DHL adalah perusahaan kargo kelas dunia. Di tingkat lokal JNT Express, Lion Parcel, TIKI, Wahan Logistics, JNE, ID Express, MSA Cargo, Megacitra adalah nama perusahaan kargo yang telah lama berkecimpung di bidang ini. Tidak ketinggalan maskapai penerbangan seperti Garuda, Lion Air, Singapore Airlines dan maskapai penerbangan lainpun ikut membuka dunia usaha kargo. Pada saat ini dunia penerbangan terbagi menjadi dua bagian : Penerbangan untuk penumpang (passenger aircraft) yaitu pesawat yang khusus untuk mengangkut penumpang, bagasi dan kargo (surat dan dokumen), Penerbangan khusus kargo (cargo aircraft) yaitu pesawat yang khusus untuk mengangkut kargo saja. Dimulai dengan pengiriman barang, klasifikasi jenis barang impor, prosedur penerimaan dan pengeluaran barang impor. Proses ini dilakukan oleh tiga pemangku kepentingan utama: Pengirim (operator pengiriman), Penerima (penerima), Pembawa. Pengirim dapat berupa individu atau entitas yang dijalankan langsung tanpa perantara atau langsung melalui pengirim barang. Pabrikan / pengirim mengirimkan kiriman ke agen pengirim / pengiriman dan melampirkan dokumentasi untuk kiriman tersebut. Maskapai / operator kemudian mengklasifikasikan semua barang ke dalam kategori kargo. Syarat Penerimaan Kargo 1. Bangunan Airway, RUU 
Maskapai Penerbangan telah diselesaikan dengan benar sesuai dengan TACT Rule 6.2. , 2. Dokumen, Semua dokumentasi yang diperlukan untuk setiap pengiriman harus disertai dengan dokumentasi tambahan yang diperlukan lainnya. 3. Penandaan Paxkage, Semua pengiriman untuk setiap pengiriman harus ditandai dengan yang berikut: Menampilkan nama penerima, nama jalan, dan alamat sesuai dengan MAWB. 4, Pengepakan Isi setiap pengiriman harus benar dikemas sesuai dengan batasan pengiriman normal. Barang berbahaya harus dikemas sesuai dengan peraturan IATA. Untuk peraturan barang berbahaya, lihat Peraturan IATA Living Things untuk hewan hidup, 5. Label paket, Label harus benar-benar terlihat dan semua label atau tanda yang telah diganti untuk waktu yang lama perlu diganti, 6. Deklarasi pengirim barang berbahaya, Dokumen ini harus ditandatangani dan dilengkapi sesuai dengan Peraturan IATA Dangerous Goods, 7. Otentikasi Pengirim Hewan Hidup Dokumen ini harus ditandatangani dan dilengkapi sesuai dengan Peraturan IATA Dangerous Goods. Cargo Handling dapat berjalan baik apabila sistem dan prosedur serta sarana dan prasarana yang dimiliki gudang dan pergudangan di masing-masing stasiun mencukupi dan pelaksanaan pekerjaan dilakukan dengan benar sesuai operating procedure. 1. Sistem Untuk pembuatan bukti timbang barang / BTB digunakan program yang di-install dalam Computer. Manifest Cargo dibuat dengan mengisi form yang telah tersedia. 2. Prosedur Setiap gudang mempunyai acuan kerja yaitu Standard Operation Procedure (SOP); berupa tindakan yang harus dilaksanakan petugas gudang agar pekerjaan operasional dapat berjalan lancar. Peraturan mengenai syarat dan tata cara menerima, menyusun barang kiriman ke pallet dan kontainer serta menarik dan memuat barang ke pesawat secara korporasi terdapat dalam manual Airlines. Peraturan lainnya terdapat dalam Cargo Information Notice sebelum dibakukan dalam manual. 3. Sarana \& Prasarana di Gudang Sarana dan prasarana yang ada di gudang antara lain Timbangan, Computer, Printer, Ruang kantor, telepon, Mesin X Ray, Mesin Telex, Fasilitas bergerak, Fasilitas tidak bergerak. Tiap negara harus memiliki prosedur penanganan dan peraturan yang jelas untuk menjamin barang-barang berbahaya sudah ditangani secara benar. Sesuai dengan ketentuan konvensi chicago bahwa setiap negara harus memasukkan aturan pengangkutan barang berbahaya ke dalam hukum nasional mereka.

\section{B. LANDASAN TEORI}

Angkutan udara menurut Peraturan Pemerintah Nomor 40 tahun 1995 adalah setiap kegiatan dengan menggunakan pesawat untuk mengangkut penumpang, kargo, dan pos untuk 
satu perjalanan atau lebih dari satu bandara ke bandara yang lain atau beberapa bandara. (Peraturan Pemerintah Nomor 40 tahun 1995 tentang Angkutan Udara.)

Bandar udara adalah lapangan terbang yang digunakan untuk mendarat dan lepas landas pesawat udara, naik turun penumpang dan / atau kargo dan / atau pos, serta dilengkapi dengan fasilitas keselamatan penerbangan dan sebagai tempat perpindahan antar moda transportasi.Sedangkan Bandar Udara Umum adalah Bandar udara yang dipergunakan untuk melayani kepentingan umum. (Kepmenhub No.KM 48 tahun 2002)

Menurut Keputusan Menteri Perhubungan Nomor : KM 11 Tahun 2010 Tentang Tatanan Kebandarudaraan Nasional : Bandar Udara adalah kawasan di daratan dan/atau perairan dengan batasbatas tertentu yang digunakan sebagai tempat pesawat udara mendarat dan lepas landas, naik turun penumpang, bongkar muat barang, dan tempat perpindahan intra dan antarmoda transportasi,yang dilengkapi dengan fasilitas keselamatan dan keamanan penerbangan, serta fasilitas pokok dan fasilitas penunjang lainnya, yang terdiri atas bandar udara umum dan bandar udara khusus yang selanjutnya bandar udara umum disebut dengan Bandar udara.

Menurut Rustian Kamaluddin (2003:3), transportasi adalah kegiatan pemindahan barang (muatan) dan penumpang dari suatu tempat ke tempat lain. Unsur-unsur transportasi meliputi : 1. Manusia yang membutuhkan 2. Barang yang dibutuhkan 3. Kendaraan sebagai alat/sarana 4. Jalan dan terminal sebagai prasarana transportasi 5. Organisasi (pengelola transportasi) Transportasi sebagai dasar untuk pembangunan ekonomi dan perkembangan masyarakat serta pertumbuhan industrilisasi.

Pengertian Strategi Pemasaran Menurut Tjiptono, Chandra, dan Adriana (2008:283), strategi pemasaran merupakan rencana yang menjabarkan ekspektasi perusahaan akan dampak dari berbagai aktifitas atau program pemasaran terhadap permintaan produk atau lini produknya di pasar sasaran tertentu. Strategi pemasaran mengandung keputusan dasar tentang pengeluaran pemasaran, bauran pemasaran, dan alokasi pemasaran.

Porter (1995:5) mengatakan : "competition is at the core of the success or failure of firms". Persaingan adalah inti dari kesuksesan atau kegagalan perusahaan. Terdapat dua sisi yang ditimbulkan oleh persaingan, yaitu sisi kesuksesan karena mendorong perusahaanperusahaan untuk lebih dinamis dan bersaing dalam menghasilkan produk serta memberikan layanan terbaik bagi pasarnya, sehingga persaingan dianggapnya sebagai peluang yang memotivasi. Sedangkan sisi lainnya adalah kegagalan karena akan memperlemah perusahaanperusahaan yang bersifat statis, takut akan persaingan dan tidak mampu menghasilkan 
produk-produk yang berkualitas, sehingga persaingan merupakan ancaman bagi perusahaannya.

Menurut Kotler (2001:295) Identifikasi Pesaing Ada 4 (empat) tingkat persaingan, berdasarkan tingkat subtitusi produk menurut Kotler, yaitu: 1. Persaingan Merek, terjadi apabila suatu perusahaan menganggap para pesaingnya adalah perusahaan lain yang menawarkan produk dan atau jasa serupa pada pelanggan yang sama dengan harga yang sama 2. Persaingan Industri, terjadi apabila suatu perusahaan menganggap para pesaingnya adalah semua perusahaan yang membuat produk atau kelas produk yang sama. 3. Persaingan Bentuk, terjadi apabila suatu perusahaan menganggap para pesaingnya adalah semua perusahaan yang memproduksi produk yang memberikan jasa yang sama. 4. Persaingan Generik, terjadi apabila suatu perusahaan menganggap para pesaingnya adalah semua perusahaan yang bersaing untuk mendapatkan rupiah konsumen yang sama.

Jenis lingkungan pemasaran perusahaan menurut Proctor (2000:122-134) adalah sebagai berikut: a. Lingkungan Politik (Political Environment) Kondisi lingkungan politik dapat memberikan pengaruh meski sering kali tidak begitu nyata dirasakan. b. Trens in Distribution Tren dapat mempengaruhi lingkungan secara tidak langsung, tetapi dapat menentukan kelangsungan pemasaran perusahaan. c. Lingkungan Budaya (Cultural Environment) Lingkungan budaya merupakan institusi dan kekuatan yang mempengaruhi nilai-nilai dasar masyarakat, persepsi, preferensi, dan perilaku. d. Kompetisi (Competition) Dunia bisnis adalah dunia yang keras. Salah satu yang membuat dunia ini penuh dengan intrik adalah karena persaingan. e. Lingkungan Teknologi (Technologycal Environment) Pemahaman terhadap pengaruh teknologi, baik terhadap perilaku kosnumen, maupun terhadap proses bisnis yang dijalankan, sangat menentukan perkembangan perusahaan f. Lingkungan Ekonomi Perekenomian memiliki pengaruh penting pada aktivitas lingkungan pemasaran seperti Produk Domestik Bruto (PDB) seluruh negara, yang pada akhirnya memengaruhi pendapatan masyarakat g. Lingkungan Hukum Hidup dan kehidupan bisnis perusahaan tidak terlepas dari perkembangan hUkum dan kebijakan pemerintahan negara dimana mereka menjalankan kegiatan bisnisnya.

\section{METODE PENELITIAN}

Penelitian ini menggunakan pendekatan sosiologi manajemen strategi perusahaan yang membantu peneliti melihat fenomena yang terjadi dan berkaitan dengan penelitian ini. Penelitian terhadap tulisan menggunakan metode kualitatif. Metode penelitian ini merupakan 
studi literatur dengan membandingkan beberapa teori yang ada, penelitian sebelumnya. Untuk memperoleh informasi dan data yang diperlukan dalam penulisan ini maka digunakan tehnik pengumpulan data sebagai berikut dokumen atau kepustakaan, yaitu teknik memperoleh data dengan mempelajari dokumen-dokumen yang berhubungan dengan permasalahan yang diteliti. Teknik analisis data dalam penelitian ini menggunakan metode analisis secara kualitatif dengan pola berfikir induktif. Proses analisis tersebut dilakukan dengan teknik analisis data yang bersifat konten analisis yaitu melalui tahap pendiskripsian secara rinci, sifat, ciri dan substansi data serta konteksnya, kemudian secara teoritik interpretatif dan menggunakan logika induksi kemudian ditarik suatu kesimpulan.

\section{PEMBAHASAN}

Dewasa ini dunia cargo udara bisnis menghadapi beberapa tantangan besar, seperti tumbuh pesatnya industri perusahaan jasa titipan/perusahaan cargo dan ditambah lagi beberapa airlines membuka usaha sejenis juga, kemajuan-kemajuan ini telah merangkul negara-negara di seluruh dunia ke dalam satu ekonomi global, Dalam ekonomi global, perusahaan harus menanggapi kecenderungan pasar seraya tetap bertanggung-jawab melindungi lingkungan. Mereka juga harus memusatkan perhatian pada pelanggan jika mereka ingin berhasil di pasar global. Proses manajemen strategis membantu organisasi mengidentifikasi apa yang ingin mereka capai, dan bagaimana seharusnya mereka mencapai hasil yang bernilai, besarnya peranan manajemen strategis semakin banyak diakui -pada masa-masa ini dibanding masa-masa sebelumnya. Maka dari itu kiranya perlu diuraikan strategi-strategi yang selayaknya dilakukan perusahaan-perusahaan dalam menyongsong era globalisasi. Manajemen strategis merupakan proses atau rangkaian kegiatan pengambilan keputusan yang bersifat mendasar dan menyeluruh, disertai penetapan cara melaksanakannya, yang dibuat oleh pimpinan dan diimplementasikan oleh seluruh jajaran di dalam suatu organisasi, untuk mencapai tujuan. Ada lima tugas manajemen strategi di dalam perusahan cargo udara yaitu $\square$ mengembangkan visi strategi dan misi bisnis, menentukan tujuan.

$\underline{\text { mengformulasikan strategi untuk mencapai tujuan, mengidentifikasikan dan melaksanakan }}$ strategi, mengevaluasi strategi.

Visi strategi Visi strategi ialah suatu tujuan tentang arah ke depan dan tindakan bisnis suatu organisasi. Konsep yang memandu perusahaan untuk melakukan sesuatu dan menjadi sesuatu. Misi mendefinisikan visi perusahaan dan memberikan tinjauan yang jelas tentang apa yang ingin dilakukan untuk pelanggannya. Dalam membuat misi, kita hendaknya 
mempertimbangkan segala kemampuan dan kelemahan yang ada, sehingga isi dari misi bukan menjadi suatu angan-angan atau janji-janji. Dengan mengembangkan dan mengkomunikasikan misi bisnis dan visi strategik, manajemen dapat menanamkan pada pekerja tentang pengertian dan maksud yang meyakinkan arah perusahaan pada masa yang akan datang. Menentukan Tujuan Strategi Tujuan adalah tanggung jawab manajemen untuk mencapai hasil atau prestasi dalam waktu tertentu. Tujuan strategi dapat ditetapkan untuk semua bidang berikut : pemasaran, kemampulabaan, sumber daya fisik dan keuangan, produktivitas / efisiensi, kinerja karyawan, pengembangan manajemen, inovasi termasuk produksi, proses dan administratif, tanggung jawab sosial, tanggung jawab pemilik, luas / pertumbuhan / difersifikasi. Manajemen Strategi Dalam Menghadapi Era Globalisasi Formulasi strategi Formulasi strategi mengandung pengembangan misi bisnis, mengidentifikasi ancam eksternal organisasi, penentuan kekuatan dan kelemahan internal, menentukan tujuan jangka panjang, membangkitkan strategi alternatif dan pemulihan strategi yang khusus. Issue formulasi strategi mengandung keputusan bisnis baru apa yang akan masuk, bisnis apa yang gagal, bagaimana mengalokasi sumber daya, bagaimana mengekpansi perusahaan atau difersifikasi, bagaimana masuk dalam pasar internasional, bagaimana merger untuk membentuk join-venture dan bagaimana menghindari bertentangan. Implementasi Strategi Implementasi strategi dibutuhkan suatu perusahaan untuk menghasilkan tujuan tahunan, menciptakan policy, motivasi pekerja dan mengalokasi sumber daya sehingga strategi yang sudah diformulasikan sudah bisa dilaksanakan. Implementasi strategi mengandung unsur-unsur pengembangan suatu budaya strategi yang sportif, menciptakan struktur organisasi yang efektif, mencari peluang baru dalam pemasaran, menyiapkan anggaran, mengembangkan dan menggunakan sistem informasi dan menghubungkan kompensasi pekerja dengan pelaksana organisasi. Implementasi strategi seringkali disebut tingkat aksi dari manajemen strategi. Implementasi strategi dimaksudkan untuk memobilisasi pekerja dan manajer untuk melaksanakan strategi yang sudah diformulasikan ke dalam aksi. Sering kali disebut sebagai tingkat tersulit dalam manajemen strategi, sebab implementasi strategi membutuhkan disiplin, komitmen dan pengorbanan. Evaluasi strategi Evaluasi strategi adalah tingkat terakhir dalam manajemen strategi. Tiga pokok evaluasi strategi adalah: $\square$ Memeriksa kembali faktor- faktor eksternal dan internal yang merupakan dasar dari strategi yang berjalan, pengukuran kinerja, mengambil langkah-langkah perbaikan. Ancaman Masuknya Pendatang Baru Pendatang baru yang masuk ke dalam industri dapat menyebabkan intensitas persaingan meningkat. Besar kecilnya ancaman tersebut ditentukan oleh ada 
tidaknya hambatan bagi pendatang baru untuk memasuki industri. Besar kecilnya hambatan masuk, antara lain ditentukan oleh hal berikut. 1. Skala ekonomi 2. Diferensiasi produk 3. Capital requirement 4. Switching cost 5. Akses ke saluran distribusi 6. Kebijakan pemerintah, Pandangan dinamis tentang keunggulan bersaing, menurut D'Aveni didasarkan pada tiga prinsip dasar berikut. 1. Interaksi Strategis yang Dinamis Prinsip pertama, bahwa dalam strategi bersaing, semua aksi sebenarnya adalah interaksi. Setiap langkah strategis yang diambil perusahaan sebenarnya adalah counte rmove atau sebagai antisipasi terhadap langkah pesaing. Dalam setiap interaksi yang dinamis, suatu perusahaan yang mengambil langkah untuk mendapatkan keunggulan sementara akan segera dibalas oleh pesaing untuk menetralisasi persaingan atau mendapatkan keunggulan baru. Perusahaan pertama akan terpaksa mengambil tindakan balasan lagi dan situasi itu akan terus berlanjut sehingga situasi persaingan dalam industri tersebut akan menjadi lebih ketat. Strategi adalah Relatif Prinsip kedua yang mendasari pandangan baru tengang keunggulan bersaing adalah bahwa tidak ada strategi yang mutlak, semuanya relatif. Posisi persaingan suatu perusahaan serta ketahanan keunggulan yang dimilikinya selalu dilihat dalam hubungannya dengan pesaing. Posisi perusahaan A dikatakan kuat sebagai low cost producer, kalah semua pesaing berada pada posisi yang lebih lemah. Artinya, biaya mereka lebih tinggi daripada perusahaan A. Begitu pula dalam hal ketahanan keunggulan yang dimiliki suatu perusahaan, hal itu dilihat dari reaksi pesaing terhadap keunggulan tersebut. Kecendrungan dalam Empat Arena Persaingan Prinsip ketiga adalah posisi strategis suatu perusahan tidak hanya relatif terhadap para pesaing tetapi juga dilihat dalam konteks sejarah interaksi yang dilakukan oleh pesaing. Oleh sebab itu, pesaing harus memproyeksikan kecendrungan jangka panjang untuk memahami ke mana arah persaingan tersebut. Keempat arena persaingan yang diuraikan menyediakan suatu kerangka yang berguna untuk menelusuri interaksi strategis yang dinamis antara pesaing dalam jangka waktu yang panjang dan untuk memahami evolusi industri. Strategic Management 1. Strategic planning tidak akan berguna bila tidak ada dukungan, masukan, dan komitmen dari lower level manager. 2. Planning harus terintegrasi dengan sistem administrasi yang ada di perusahaan, seperti management control, komunikasi dan informasi, serta motivasi dan rewards. 3. Sistem adminstrasi dan struktur organisasi harus dapat dikoordinasikan dengan baik dengan culture (budaya) dari perusahaan 


\section{E. KESIMPULAN}

Dapat disimpulkan bahwa manajemen strategik pada perusahaan jasa cargo udara sangat perlu di formulasikan agar bisnis dapat berjalan dengan lancar dan tetap dapat bersaing dengan kompetitor sejenis, manajemen strategi diasumsikan sebagai kumpulan dan tindakan yang menghasilkan perumusan (formulasi) dan pelaksanaan (implementasi) rencana-rencana yang dirancang untuk mencapai sasaran-sasaran organisasi, perencanaan berskala besar (disebut perencanaan strategi) yang berorientasi pada jangkauan masa depan yang jauh (disebut visi), dan ditetapkan sebagai keputusan pimpinan tertinggi (keputusan yang bersifat mendasar dan prinsipil), agar memungkinkan organisasi berinteraksi secara efektif (disebut misi), dalam usaha menghasilkan sesuatu (perencanaan operaional untuk menghasilkan barang dan/atau jasa serta pelayanan) yang berkualitas, dengan diarahkan pada optimalisasi pencapaian tujuan (disebut tujuan strategis) dan berbagai sasaran (tujuan operasional) organisasi. Manajemen strategis menurut Nawawi adalah perencanaan berskala besar (disebut perencanaan strategi) yang berorientasi pada jangkauan masa depan yang jauh (disebut visi), dan ditetapkan sebagai keputusan pimpinan tertinggi (keputusan yang bersifat mendasar dan prinsipil), agar memungkinkan organisasi berinteraksi secara efektif (disebut misi), dalam usaha menghasilkan sesuatu (perencanaan operaional untuk menghasilkan barang dan/atau jasa serta pelayanan) yang berkualitas, dengan diarahkan pada optimalisasi pencapaian tujuan (disebut tujuan strategis) dan berbagai sasaran (tujuan operasional) organsasi.

\section{F. DAFTAR PUSTAKA}

Republik Indonesia, 1995. Peraturan Pemerintah No. 40 tahun 1995 tentang Angkutan Negara. Lembaran Negara Republik Indonesia Tahun 1995 No. 68. Sekretariat Negara. Jakarta

Keputusan Menteri Perhubungan Nomor : KM 11 Tahun 2010 Tentang Tatanan Kebandarudaraan Nasional

Keputusan Menteri Perhubungan Nomor KM 48 Tahun 2002 tentang Penyelenggaraan Bandar Udara Umum

Kotler, Philip and Kevin L. Keller. 2009. Marketing Management. Alih Bahasa; Benjamin Molan. Edisi ke dua belas, Jilid I. Jakarta: PT INDEKS

Porter, Michael E. 2007. Strategi Bersaing. Alih Bahasa; Sigit Suryanto. Tangerang: KARISMA publishing Group

Proctor, Tony. 2000. Strategic Marketing: an Introduction, London \& New York: Routledge 
Aviasi: Jurnal Ilmiah Kedirgantaraan

Volume 17 Number 2 (2020)

Tjiptono, Fandy, Georgius Chandra dan Dedi Andriana, 2008. Pemasaran Strategik. Yogyakarta : Penerbit ANDI. 